\title{
The Relationship Between Sci-Fi Films and Chinese Politics
}

\author{
Rui $\mathrm{Xu}^{1, *}$ \\ ${ }^{1}$ Fuzhou University of International Studies and Trade, Fuzhou, Fujian, China \\ *Corresponding author. Email: 635524937@qq.com
}

\begin{abstract}
It could be said that science fiction films represent on the most accomplished forms of popular film art. However, according to Daily Box Office listings, in recent decades there have been almost no Chinese science fiction films listings on the box office (1980- present). Not only do few Chinese science fiction films appear in the international market, but it is also apparent that the domestic science fiction industry (written science fiction, science fiction films, etc.) was initiated at a relatively later stage compared to developed countries such as those in Europe and the United States (Linus Fredriksson, 2015: 4).
\end{abstract}

Keywords: relationship, sci-fi films, Chinese politics

\section{INTRODUCTION}

It can be said that when we consider the past of the Chinese film industry in general, it is apparent that the number of high quality science fiction films in China is absolutely minimal. Although Chinese society has endured feudal rule and a policy of seclusion, it may be have surmised that the advocates of Chinese culture recognised and redefined the approach towards the optimism of science and modernisation during the May Fourth Movement in 1919 (Linus Fredriksson, 2015: 4). This statement could also apply to the establishment of the People's Republic of China in 1949 when, for the first time in the 150 years, China was able to avert civil war and embark on the road to industrialisation. The rapid and stable social environment, the increasing availability of education, and the incorporation of popular science into national planning may also have led to an increasing sense of creativity and the desire to depict many possible colorful things in the future. Factors such as these might seem to have provided a sound basis for the development of Chinese science fiction films. However, what happened was quite the opposite. I will argue that China's political systems and approach to film censorship are the reason for the lack of Chinese science fiction films. The impact of these factors on the nation's creative industry may generally be considered to be negative. (Here, China refers specifically to Mainland China.) In order to address this negative influence, in this paper I will provide some reasonable suggestions for the future development of China's science fiction films. This paper, in general, consists of four main chapters. Chapter 1 principally expounds the close connection between the art of film and politics. It aims to clarify the correlation between science fiction films and national politics. Chapter 2 tentatively examines the negative influence of China's special political systems (the State Administration of Radio Film and Television, SARFT, and its censorship) on the development of China's science fiction films. Chapter 3, based on the causes cited in Chapter 2 analyses problems which exist in China's political systems and the issue of censorship. It offers considered recommendations which may assist in securing a brighter future for Chinese science fiction films. The last chapter serves as a summary for the entire paper.

\section{A. The relation between films and politics}

In the field of politics, the politics of culture remains a key focus. From Montesquieu to Tocqueville's French Sociology and from Kant to Weber's German Cultural Philosophy, the close relation between politics and culture has been thoroughly discussed. Film, as a relatively new facet of the modern culture industry is liable to carry certain ideological influences. It may be subject to 'social unconsciousness' and 'political unconsciousness'. Since film is produced under the influence of a certain historical and social background, it is bound to imply the ideology of a particular party or social class. Namely, the humanism of film determines its theme in the social sense, which meanwhile determines its ideological and political bearing. As a Chinese scholar insists, 'The connection between the theme of the film and the politics is unavoidable.' A Comparative Study of Films (China Film Publishing House, 2000: 234). 


\section{B. The relations between science fiction films and politics}

As has been previously mentioned, films and politics are closely related. Science fiction films also present some new possibilities regarding the relationship between cinema and politics. Film is a visual art form. The medium can depict familiar everyday environments or portray newly imagined worlds which go beyond reality. Moreover, films can potentially exist within an ideal dimensionality. When experiencing these films, audiences can imagine new, alternate ways of life and existence, surpassing the limitations of life and contemporary times. Not every imagined scenario presented is entirely positive. Films can reflect the social reality of different eras through documentary methods. Further to this, film offers the potential to explore prospective modes of thought, philosophies, situations, or aesthetics. The medium allows for the formulation and sensory presentation of worlds which encompass positive or negative visual art which exists outside of the realm of contemporary social environments. In this sense film can offer a notional portal into the future. To some degree, film can deepen understandings and thoughts of a personal nature, as well as social relationships, social systems, contradictions and human conditions. In addition, science fiction films can be considered to be futuristic fantasies. This position outside of the "real world", allows the implicit contemplation of politics and social issues. The scientific fiction film Avatar is a good example. According to Ellen Grabiner, critics have argued that the film is "sexist, anti-imperialist, antimilitaristic, racist, anti-capitalistic, leftist, reactionary, and pro-environment (Jennifer P. Nesbitt,2012:21).

In some way, science-fiction film of M. Knight Shyamalan, The Happening (2008) showed this reflection. Firstly, it introduced paranoia and legend in relation to early American terrorists. Puzzling masssuicide events have certainly occurred in the real world. In this film, these events were said to have been committed by terrorists, and then to be directed towards the government. The unknown source of terror expressed the violence and cultural negativity of the era of Bush and Cheney. The Happening depicted multiple revolts against centralised power and sexism. In another contemporary film, The Hunger Games (2012), people in the future have constructed new homes following a period of warfare. Under the new centralised power, there are 12 districts, each of which must offer a man and woman as tributes to join the "Hunger Games". Only one can remain as 24 people fight other. The series of The Hungry Games exhibited the alienation of human nature through the abnormal technique of development with centralism. The film The Fifth Element (1997) exhibited a distinct suspicion of attitudes regarding capitalism and consumption. In addition, it also explored the political corruption.
(Hayward, Susan; Powrie, Phil, 2009) All of these films relate to political and social problems. As Douglas stated, the film is not only a form of business. In the present time, when a particular group exhibits frustration within society, Hollywood hurriedly produces a film in order to express this sense of dissatisfaction and anger regardless of who is in power at the time. Although the Conservative Party is in office, it is still apparent that many liberal, films which are critical of contemporary politics and society are produced. On one hand, a film can be wholly imaginative; on the other hand, it may also be closely related to reality. In brief, the science-fiction film offers the opportunity to discuss sensitive problems regarding, for example, politics and race.

\section{Science fiction films and Chinese politics}

Similarly, in China, films are neither, purely art nor purely a product for sale. They contain complicated structures with multiple social cultures and complex processes with varying power relationships. In fact, we can feel deep conflict and compromise between the initial growth of the Chinese film industry and the sense of regulation which the Chinese government pushes. Although the Chinese government have allowed for a number of comprehensive privileges in terms of the investment, in film-making, film distribution and screenings, in order to fully realise film marketisation, the film as a means of the transmission of national ideology must not decry mainstream values and the overall cultural consensus. In the Chinese political system, science fiction films do not occupy a positive living environment. To a certain degree, the possibilities which the science fiction film can provide are subdued. The opportunity to discuss sensitive issues in contemporary society, such as politics and race is often denied. It is apparent that this concept does not adhere to the prescribed values of the Chinese State. The country ruled by one Party and Chinese media (in particular films) are subject to both the dictation of the state and harsh market competition. (Margarita Vivian, 2014: 108). According to the stipulations of the Communist Party, the film industry must act in accordance with international standards. However, this does not necessarily represent a path to liberalism or unbridled openness which may pose a challenge to the authority of the Party (Darrell William Davis,2010: 122). Time travel, for example, is a staple theme of science fiction films. In China the genre has grown in popularity in recent years. (For further details on the science fiction film's conclusions regarding time travel in recent years, see Attachment 1). Contemporary viewers are likely to see an individual return to ancient China, experience an adventure and finally find a lover and ultimate happiness. In an interview featured in Hollywood Report, the film critic, Raymond Zhou provided another reason as to why censors were eager to dismiss science-fiction films: "in some degree, this 
setting can make comments on contemporary social fashionable trends and current events, actually not based on scientific technology". (Jonathan Landreth, 2011: 1) Since the 90th anniversary of the foundation of the Communist Party of China (CPC), China's media authorities have stopped the clock regarding the depiction of time travel in film and television, stating that this sci-fi notion "disrespects history." As with other freedoms - artistic, academic, religious, journalistic — "freedom" in the marketplace is accepted to a limited degree, but it is ultimately subject to the approval of the authorities. This is widely understood in China and is subject to official enforcement (Darrell William Davis, 2010: 123).

\section{WAYS FOR CHINESE POLITICS TO AFFECT SCIENCE FICTION FILMS}

\section{A. China's film censorship institutions (SARFT)}

In the last chapter, arguments were addressed regarding the conditions which Chinese science fiction films occupy under Chinese film censorship institutions. This chapter mainly discusses the ways in which Chinese politics negatively affects science fiction films. It is divided into two sections: China's film censorship institutions (SARFT) (2.1) and different periods of government policy on literature and art (2.2).

Inspection systems of films in the world are divided into two models. One is 'beforehand' film censorship within the Chinese mainland, which is reliant on different rating systems than those of America, Britain, Canada, India and Hong Kong. Beforehand censorship means that the administration checks the film prior to distribution and screening. the aesthetic freedom of film workers.

It is clear, however, that China's censorship institution (SARFT) is more intolerant than other countries regarding attitudes towards politics, social reform and extreme environmental issues. "It seems to be a political minefield to portray China today, especially if it is to portray some negative things." This statement becomes easier to understand when we consider China's review of the content and type of film. According to the provisions of the Chinese film script (outline) filing, the provisions of the film management: adopted at the meeting of the Council on 3rd April 2006 , and it is hereby promulgated, and implemented from June 22nd, 2006. The Article 14 provides that the film should be edited for modification in case of the following circumstances:

mixed with murder, violence, terror content, reverses the value orientation of true and false, good and evil, beauty and ugliness, confuses the basic nature of justice and injustice; deliberately manifests the crime of arrogance, specifically shows the details of criminal behavior, or exposes special investigation means; (2) there is strong irritation about the murder, bloody, violent plot, drug abuse, gambling and other circumstances; there is abuse of prisoners, torture of criminals or criminal suspects and other circumstances; excessive horror on screen, in lines, background music and sound effects; (3) advocating religious extremism and provoking contradictions between religions, sects, believers and non-believers and the contradictions between the religious (4) promoting the destruction of the ecological environment, animal abuse, killing, consumption of national protected animals; (5) excessive performance of alcoholism, smoking and other bad habits; (6) violating the relevant laws and regulations. Although the Chinese film review standards are varied, they can be summarised essentially into four distinct aspects: pornography, violence, morality and politics.

\section{B. Different strategies for the development of government policies on literature and art during different periods of history}

The development of the science fiction industry, in addition to the previously addressed strict control by the SARFT on science fiction film values and content, is likely to be affected by the current government's cultural policy. In other words, as time goes by, Chinese political institutions are liable to treat science fiction and science fiction films in different ways at different times. Especially in the specific historical period and cultural background, such as the "political ideology control on the field of literature and art in the special period, the common art standards "political standards first, art standards second." should be strictly followed.

\section{FUTURE DEVELOPMENT OF SCIENCE FICTION FILMS AND CHINA'S POLITICS}

After discuss the political influence in relation to the development of China's science fiction films in the above two chapters, I believe that China's political environment has, to some extent, curbed the latter. The negative influence mainly comes from China's strict political censorship, and political guidelines formulated by the Chinese government for the development of arts and culture in different periods of time. Thereby, in this chapter, I will attempt to examine problems relating to China's current censorship and propose some viable improvement plans so as to contribute to a flourishing of science fiction novels in China. If China wants to make a breakthrough in relation to its science fiction films, implementation of the grading system is a good method to achieve the diversified development of film culture. The film grading system of the US not only protects teenage audiences, but also enables film artists to give full play to their artistic expression, thus 
bringing more diversity to American film culture. It is therefore apparent that American practices could be beneficial to China. "To make films catering to both the young and the old" can just be a hope in vain. Only when the audience market is carefully analysed can a film creation be successful. Just as Tong said, It will greatly encourage the creative enthusiasm of the film artists and the development of China's motion picture industry, and boost international co-operation and collaborations between Chinese film-makers and their foreign counterparts (Zhu Linyong, 2004). However, film censorship still dominates in China, leaving little space for the grading system. In fact, throughout China's film history, film grading was also implemented for a period of time. In 1989, the SARFT issued the "Notice on Censorship and Release Grading System of Some Films", which restricts four films from being exposed to children. The Notice also claimed that relevant administrative regulations would be introduced after taking heed of suggestions from all sides for one year. However, so far, no administrative regulations have been formulated. Along with increasing opening of China's film market to the outside world, film grading has been a general requirement of all sectors of society. In the past decade, some CPPCC members have submitted proposals of film grading, which, however, have received no replies from the superior level. In fact, both film censorship and film grading are introduced for the purpose of protecting the physical and mental health of minors. The former mainly concerns about whether a film "can be made or released", while the latter deals with "to whom the film is suitable". Based on China's national conditions, film grading can be introduced under the prerequisite of film censorship. The two are not contradictory to each other, but can be organically integrated to boost development of China's sci-fi film industry.

\section{A. Setting up film grading institutions}

The film grading institutions can be built on the current film association through the latter's restructuring. The grading personnel should be made up of the association members (mainly professionals within the film industry) and the social public from all sectors and representing interests of different social groups.

\section{B. Formulating film grading standards}

The film grading standards should be further refined based on the current film censorship standards. During formulation process of censorship standards, opinions of professionals and the social public are both important. The film grading standards should be evaluated and modified on a regular basis.

\section{Drawing up film grading procedures}

The film censorship institutions and the film grading institutions should work together in order to viably censor films. Firstly, the film grading institutions should grade a film. Then, the film censorship institutions issues the censorship result based on the grading. Following this, the film is sent to the film grading institutions for re-grading. The grading opinion is copied to the film censorship institutions for filing. The film is sent to the film censorship institutions for another censorship. If it passes the censorship, it can take the "Film Release License" to the film grading institutions for final grading.

\section{Introducing film grading review procedures}

If a filmmaker or producer does not accept the film grading outcome, he or she can apply to the film grading institutions for another grading. The film grading institutions should then employ different personnel to undertake another grading of the film.

\section{E. Reforming film theater chains}

The specialised film chains and the mass theater chains should be distinguished from each other. The former is for films which fail to get the release license from the film censorship institutions but are graded by the film grading institutions. However, specialised film chains should be operated under strict management. Those films which are unsuitable for minors should give clear suggestions on not having minors exposed to these films. Mass theater chains are for films which have got the film license from the film censorship institutions and been graded by the film grading committee.

\section{CONCLUSION}

According to the confirmation in the last several chapters, I still think that the Chinese political system has a very close connection with the industry of Chinese science fiction films and it has exerted a negative influence on Chinese science fiction films. We can say that, at present, the Chinese political system and censorship do more harm than good to Chinese science fiction movies. What's worth investigation and discussing is that our political environment will get more and more relaxed and that the censorship system for films and the rating system will interfere with movie in a more appropriate way as time goes by, for which we have faith. Thus, the relationship between Chinese science fiction movie and politics will be greatly improved in comparison to its previous status. Though the development of Chinese science fiction film has been full of difficulties and challenges and it is hard for us to come to a new high in a short time, we are still full of hope that we can be ushered into a new era of Chinese science fiction films. 


\section{References}

[1] Darrell William Davis, 2010, Market and Marketization in the China Film Business, Cinema Journal49 ,No.3, pp121-125.

[2] David Roth-Lindberg, 2011, "Den kinesiska filmindustrin under början av det nya milleniet", Kinarapport, Scenkonst och film Vol.2, p.26

[3] Elisabeth R. Anker, 2014,Orgies of Feelings: Melodrama and the Politics of Freedom, (Durham, NC: Duke University Press, ISBN-13:978-0822356974, p3.

[4] Han Song, 2013, Chinese Science Fiction: A Response to Modernization, Science Fiction Studies, Vol.40.

[5] Han Song, 1997,"The Social Environment of Chinese Science Fiction", '97 Beijing International Conference on Science Fiction: Essays pp. 110-112, at p. 110.

[6] Hayward, Susan, Powrie, Phil. 2009 The Films of Luc Besson: Master of Spectacle. [D]. Manchester: Manchester University Press.

[7] Jack Valenti, Ratings History [EB/ OL]. http://www. mpaa.org ratings2history I. asp. 2005204216.

[8] James M. Hargett 1981, Two Writers and the Cultural Revolution: Lao She and Chen Jo-hsi by George KaoVol. 55, No. 2, A Look at Chinese and African Letters (Spring, 1981), pp. 372-373.

[9] Jasmine Shadrack, 2011, V versus Hollywood: A discourse on polemic thievery,Studies in Comics, Volume 2 Number 1,STIC 2 (1) pp. 195-205.

[10] Jennifer P. Nesbitt, 2012, Deactivating Feminism: Sigourney Weaver, James Cameron, and Avatar,Film \& History 46.1 (Summer) pp 21-32.

[11] Krishan Kumar,1989 Utopia and Anti - Utopia in Modern Times [M]. New York : Basil black well Ltd. p104.

[12] Lan Wei, 1961, "Discussing Science Fantasy Films" (tantan kexue huanxiang de yingpian), Film Art, No.04, p. 42-43.

[13] Lilly, J, Goren. 2016 Politics and Popular Culture [D]. Published online:\# Springer Science+Business Media New York.

[14] Linus Fredriksson,2015 China and Cinematic Science Fiction: A Lost Genre A brief history of Chinese science fiction film and its' narrative themes, FIVM0.

[15] Margarita Vivian, 2014, Chinese Independent Documentary Films: Alternative Media, Public Spheres and the Emergence of the Citizen Activist The University of Western Australia, Asian Studies Review, Vol. 38, No. 1, pp107-123.

[16] M. Keith Booker,2008,Alternate Americas: Science Fiction Film and American Culture,doi:10.1017/S0021875808004763, (Westport, CT and London: Praeger). Pp. viii+274. ISBN 0275 983951.

[17] Richard Curt Kraus, 2004, The Party and The Arty in China: The New Politics of Culture, Rowman \& Littlefield Publishers, p.37.

[18] Steven Early 1978, An Introduction to American Movies [M], New York: Sieget P86.

[19] Tighe, C. 1999, 'Stanislaw Lem: Socio- Political Sci-Fi', The Modern Language Review, 94: 3 (July)

[20] Vivian Sobchack, 1986 , Child /Alien/Father: Patriarchal Crisis and Generic Exchange Camera Obscura Vol.5, Nov.315.

[21] Xiao Mei, 1980 , Film Art (Dianying yishu), "Fantasy - The Soul of Science Fiction Film (Huanxiang - kehuan dianying de linghun), No.11, p.34.

[22] Yanchunjun, 2000, Chinese film comparative study, China Film Publishing House, P234.

[23] Zheng Wenguang, 1992 "Speech by Zheng Wenguang", Locus 372 (Jan), p.43. Transcript of speech given at World SF meeting in Chengdu, Sichuan.
[24] Zhu Su-Ni, 2012 Analysis on censorship of film in China form the aspect of Administrative Law, pp1-56. 